\title{
Ergosterol as an indicator of mold resistance in white and colored grain sorghum hybrids
}

\author{
V. Thirumala Rao ${ }^{\text {a }}$, P. Sanjana Reddy ${ }^{\text {b, } *}$, B.V.S. Reddy ${ }^{c}$, A. Ashok Kumar ${ }^{c}$ \\ ${ }^{a}$ RARS, Acharya NG Ranga Agricultural University, Jagtial, Karimnagar 505327, India \\ ${ }^{\mathrm{b}}$ Directorate of Sorghum Research, Rajendranagar 500 030, Andhra Pradesh, India \\ c ICRISAT, Patancheru 502 324, Andhra Pradesh, India
}

\section{A R T I C L E I N F O}

\section{Article history:}

Received 5 October 2011

Received in revised form 17 December 2011

Accepted 24 December 2011

\section{Keywords:}

Sorghum

Grain mold

Ergosterol

Hybrid

Flavan-4-ols

\begin{abstract}
A B S T R A C T
Grain mold is a serious disease of sorghum causing both qualitative and quantitative losses in grain production. There has been a drastic reduction in area and production in India due to the lack of resistant varieties to manage the disease. Genetic improvement for mold resistance has been suggested as a sole criterion for reducing losses associated with grain mold and several morphological and biochemical traits have been employed to aid screening for resistance. However, there is always a bias with visual scoring systems to rate disease severity; thus, ergosterol and flavan-4-ols content within the grain was evaluated as selection criteria. Twenty-five hybrids were selected based on their visual rating for grain mold resistance and grain color from replicated trials at two locations in India during 2004 and 2005 rainy seasons and grouped into colored resistant, white resistant, colored susceptible and white susceptible. The field grade score (FGS) and threshed grade score (TGS) were strongly and positively correlated with ergosterol content and weakly and negatively correlated with flavan-4-ols. Though the resistant hybrids had higher concentration of flavan-4-ols in methanol and acidified methanol extract compared to the susceptible hybrids, the white grained hybrids had negligible amounts indicating flavan-4-ols concentration is not a suitable selection criterion especially in white grained hybrids. The ergosterol content was higher in susceptible hybrids $(19.49 \mu \mathrm{g} / \mathrm{g})$ compared to resistant hybrids $(9.96 \mu \mathrm{g} / \mathrm{g})$ and it was marginally less in red hybrids $(14.0 \mu \mathrm{g} / \mathrm{g})$ compared to white $(17.2 \mu \mathrm{g} / \mathrm{g})$ hybrids. The highly significant correlation of ergosterol content with germination percentage, FGS and TGS validates the use of this trait for identification of grain mold resistant genotypes provided there is no delay in the estimation. Also the significant heterosis obtained for this trait indicates the existence of dominance gene action and suggests that further exploitation of this trait would benefit the development of grain mold resistant hybrids.
\end{abstract}

(c) 2012 Elsevier Ltd. All rights reserved.

\section{Introduction}

Sorghum (Sorghum bicolor (L.) Moench) is an important crop grown in the arid and semi-arid regions of the world. The growing world population together with reduction of arable area and the need to meet the global food demand expected to increase by $40 \%$ by 2020 (Andersen et al., 1999) implies that the need to raise the crop productivity is greater than in the past. Grain mold is the most important disease of sorghum worldwide reducing both grain production and quality. Current commercial hybrids are bred for earliness in India so that they escape drought. However, maturity coincides with heavy rains that greatly increase the risk of infection by grain molds (Ambekar et al., 2011). Grain mold can be broadly

\footnotetext{
* Corresponding author. Tel.: +914024018651.

E-mail addresses: sanjana@sorghum.res.in, sanjanapulluru@gmail.com (P. Sanjana Reddy).
}

defined as pre-physiological grain deterioration caused by fungal species interacting pathogenically and/or saprophytically with developing grain. Grain weathering, on the other hand, is a postphysiological maturity problem observed as grain discoloration and tissue damage by saprophytic fungal colonization due to wet weather (Thakur et al., 2007). Several species of the genera Fusarium, Curvularia, Alternaria, Phoma, Bipolaris and Colletotrichum have been reported to be associated with grain mold (Thakur et al., 2003). The disease is associated with losses in seed mass (Somani and Indira, 1999), grain density (Ibrahim et al., 1985), and germination (Maiti et al., 1985). Other types of damage that arise from grain mold relate to storage quality (Hodges et al., 1999), food and feed processing quality, and market value. Several mold-causal fungi are producers of potent mycotoxins that are harmful to human and animal health and productivity. Of the several approaches that have been tried, host plant resistance appears to be the most viable and effective method of managing grain mold. 
Breeding grain mold resistant cultivars may help improve sorghum production and profitability, extend the use of improved cultivars to new areas, as well as contribute to enhanced health of consumers (Audilakshmi et al., 1999).

Evaluation of sorghum genotypes based on visual (panicle grain mold resistance and threshed grain mold resistance) scores has led to the identification of several grain mold resistant genotypes (Bandyopadhyay and Mughogho, 1988; Ghorade et al., 1997; Audilakshmi et al., 1999; Reddy et al., 2000; Palakshappa et al., 2003). Bandyopadhyay and Mughogho (1988) also observed that light-colored grains show more grain mold than dark-colored grains with equal severity. Althoughvisual appraisal can estimate severity (degree of colonization of a uniform sample indicated by signs or discoloration), incidence (proportion of grain affected) or damage (reduction in grain size), it involves a complex of factors. Since visual appraisal evaluates the superficial condition of sorghum grain, it cannot provide information on the internal colonization of grain. Identification of biochemical compounds that are associated with grain mold resistance may solve the problem and facilitate the screening for resistant genotypes.

The association of flavan-4-ols with grain mold resistance has been demonstrated in Asia (Jambunathan et al., 1990), Argentina (Martinez et al., 1994) and USA (Melake-Berhan et al., 1996). Schutt and Netzly (1991) suggested that flavan-4-ols accumulate in sorghum grains as a biosynthetic precursor of phytoalexin apigeninidin. Fungal biomass in sorghum grain can be estimated by measuring the concentration of ergosterol, a sterol produced by fungi but not by plants (Sietz et al., 1977). Forbes et al. (1989) and Jambunathan et al. (1991) reported that the quantity of ergosterol was highly correlated to grain mold. They found that the concentration of ergosterol was 10 -fold higher in susceptible than in resistant genotypes. Similar results were reported by Audilakshmi et al. (1999) and Raju et al. (2004). The study of the contribution of ergosterol and flavan-4-ols to grain mold resistance in hybrids and heterosis for these traits can provide an insight into breeding for grain mold resistance. Sorghum hybrids are predominantly cultivated during the rainy season in India; hence, the present study was undertaken to estimate the mean and heterosis for ergosterol and flavan-4-ols content in grains of mold susceptible and resistant hybrids.

\section{Material and methods}

\subsection{Experimental material}

The experimental material was obtained from ICRISAT, Patancheru, India. It included eight A-lines (ICSA 369, ICSA 370, ICSA 371, ICSA 400, ICSA 384, ICSA 382, ICSA 52 and ICSA 101), their respective B-lines, 21 R-lines (IS 41720, IS 41397, IS 41675, IS 18758C-618-2, IS 18758C-618-3, IS 30469C-140-2, IS 30469C1508-2, ICSV 96105, ICSV 96094, IS 84, SPV 462, ICSR 89013, ICSR 91011, ICSR 89018, ICSR 89058, PVK 801, GD 65028, GD 65055, ICSR 92001, ICSR 91019 and ICSR 91029) and six checks (Bulk Y, IS 25017, IS 20, IS 14384, PVK 801 and CSH 16). The eight A-lines (5 of which were grain mold resistant) and 21 testers ( 9 of which were grain mold resistant) were crossed in Line $\times$ Tester mating design during the 2003-2004 and 2004-2005 post rainy seasons (October to February) at ICRISAT, Patancheru, India. The 203 genotypes including 168 hybrids, 8 B-lines, 21 R-lines and 6 checks were evaluated in a randomized complete block design with two replications at ICRISAT and at College of Agriculture, Acharya NG Ranga Agricultural University, Rajendranagar, India during the 2004 and 2005 rainy (June to September) seasons. Each genotype was grown in two rows of $4 \mathrm{~m}$ length with a spacing of $60 \mathrm{~cm}$ between rows and $15 \mathrm{~cm}$ between plants in a row. Recommended agronomic practices were followed to grow a good crop. Based on the grain color and field grade score (FGS), the hybrids were grouped as colored resistant (FGS equal to or less than 4), colored susceptible (FGS greater than 4), white resistant and white susceptible. From these trials, 25 hybrids were selected for grain analysis. Among the 25 hybrids, 15 hybrids ( 10 with white grain color and 5 with red grain color) were grain mold resistant and 10 hybrids (5 with white grain color and 5 with red grain color) were grain mold susceptible based on the visual rating for field grade score. Harvested grain of 48 genotypes that include 25 hybrids, their 22 parents and a susceptible check, Bulk Y, was used for estimating ergosterol and flavan-4-ols concentrations.

\subsection{Field screening technique for grain molds}

The screening technique of Bandyopadhyay and Mughogho (1988) was used to increase grain mold pressure. Sprinkler irrigation was provided twice a day on rain-free days for $1 \mathrm{~h}$ each during morning and evening from flowering to physiological maturity to create high humidity ( $>90 \%$ relative humidity) that is condusive for the development of mold on the developing grains. Ten uniformly flowered panicles were tagged in each replication for recording the data.

\subsection{Data recording}

\subsubsection{Field grade score}

Ten panicles from each replication of each test entry were scored visually for mold severity on the panicle surface at harvest, using a progressive $1-9$ scale where $1=$ no mold, $2=1-5 \%, 3=6-10 \%$, $4=11-20 \%, 5=21-30 \%, 6=31-40 \%, 7=41-50 \%, 8=51-75 \%$ and $9=>75 \%$ molded grains on a panicle.

\subsubsection{Threshed grade score (TGS)}

Ten panicles from each replication of the 25 genotypes were harvested at maturity and threshed. A sample of $35 \mathrm{~g}$ of the threshed grain from each panicle was spread in a 9-cm petri plate and scored visually for mold severity on the seed surface using the same scale as that for FGS.

\subsubsection{Seed color $(S D C L)$}

Seed color was scored visually as $1=$ white seed and $3=$ red seed.

\subsubsection{Germination percentage (GER\%)}

One hundred grains from each of the ten panicles from each replicate that was scored for TGS, were incubated in petri dishes lined with wet filter paper for $4 \mathrm{~d}$ at $30^{\circ} \mathrm{C}$, and number of germinated seed was counted (Audilakshmi et al., 1999).

\subsubsection{Estimation of ergosterol content (ERGO)}

Ergosterol content was determined according to the modified method of Jambunathan et al. (1991). Threshed grains from ten dried panicles were collected and mixed thoroughly. A $25 \mathrm{~g}$ sample of the mixed grains was ground in an Udy Cyclone mill (U.D. Corp. Boulder, CO) to pass through a $0.4 \mathrm{~mm}$ screen. Duplicate $10 \mathrm{~g}$ samples of ground grain were weighed in polythene screw cap bottles ( $125 \mathrm{ml}$ capacity), $50 \mathrm{ml}$ of methanol was added, and bottles were shaken vigorously on a reciprocating shaker for $60 \mathrm{~min}$ at room temperature. The mixture was allowed to settle and $25 \mathrm{ml}$ of clear extract was transferred into a screw-capped test tube containing $3 \mathrm{~g}$ of $\mathrm{KOH}$ and was shaken till the $\mathrm{KOH}$ dissolved. Ten milliliters of $n$-hexane was added and the mixture was incubated at $75^{\circ} \mathrm{C}$ in a water bath for $30 \mathrm{~min}$ and then allowed to cool to room temperature. Distilled water $(5 \mathrm{ml})$ was then added, the solution 
was mixed thoroughly, and the top hexane layer was removed with a pipette and transferred to a $50 \mathrm{ml}$ beaker. To the remaining aliquot in the test tube, $10 \mathrm{ml}$ of hexane was added and mixed vigorously and hexane layer was removed carefully and pooled with the earlier extract. This procedure was repeated twice and all the pooled hexane extracts in the beaker were evaporated to dry in a hot-water bath. The residue was redissolved in $5 \mathrm{ml}$ methanol (HPLC grade) and filtered through a $0.45 \mathrm{~mm}$ filter (Millex, HV, Millipore Corp. Bedford, MA).

Ergosterol was determined in a Shimadzu LC-6A High Performance Liquid Chromatograph (HPLC) with manual loading. The extract was loaded on a reverse-phase column [3 $\mu \mathrm{m}$ particle size, $6 \mathrm{~mm} \times 8 \mathrm{~cm}$ ] consisting of two $4 \mathrm{~cm}$ Zorpax Reliance Cartridges ( $\mathrm{Du}$ Pont City State). The mobile phase was methanol-water $(96: 4 \mathrm{v} / \mathrm{v})$ at a flow rate of $1.2 \mathrm{ml} \mathrm{min}^{-1}$. The column temperature was maintained at $50{ }^{\circ} \mathrm{C}$, and the absorbance of eluted ergosterol was detected at $282 \mathrm{~nm}$. The standard ergosterol (Sigma City State) had a retention time of $8.3 \mathrm{~min}$. Along with the experimental sample, a sample of standard grain mold susceptible check (Bulk Y) was also analyzed every time to maintain the accuracy of the procedure. The standard ergosterol was loaded in 2.5, 5.0, 7.5 and $10.0 \mathrm{mg}$ concentration for computation of the instrument every time. The instrument was calibrated for standard ergosterol and then ergosterol content of the sample was recorded in ppm.

\subsubsection{Estimation of flavan-4-ols (FLAV)}

The procedure of Butler (1982) was followed for estimating flavan-4-ols in grains. Grains were collected from 10 panicles from each replication and bulked. Five grams of grain was ground in an Udy Cyclone Mill. The grain powder was defatted with hexane and air dried. Duplicate of $200 \mathrm{mg}$ of defatted grain powder was taken in screw cap test tubes and $5 \mathrm{ml}$ methanol was added. Tubes containing the defatted seed material were placed on Stuart tube rotator (TR-2) and mixed for one hour. The tubes were then centrifuged for $10 \mathrm{~min}$ and the supernatant was decanted into vials. The two methanol extracts from each sample were pooled separately to form methanol extract. Five milliliters of methanol-HCL was added to the remaining residue and the procedure repeated to form methanol-HCL extract of each sample.

Methanol extract $(0.5 \mathrm{ml})$ was taken and $7 \mathrm{ml}$ water saturated butanol and HCL (70:30) was added. Simultaneously, a blank was prepared by mixing water saturated butanol, methanol and $0.1 \mathrm{~N}$ acetic acid in a 70:15:15 ratio, respectively. The tubes along with the blank were rotated in the test tube rotator for $1 \mathrm{~h}$. The same procedure was followed for methanol-HCL extract. The absorbance was read at $550 \mathrm{~nm}$ in a spectrometer (Spectronic 21, Bausch \& Lamb, USA). All the results were calculated as $A_{550} \mathrm{~g}^{-1}$ dry sample.

\subsection{Statistical analysis}

The field experiments in the different years were conducted using a randomized complete block design. The errors were tested for homoscedasticity using the Bartletts test (Bartlett, 1937). The heterogeneous variable "ergosterol content" was transformed through Aitken's transformation. Pooled data was analyzed for analysis of variance (ANOVA) and correlations were drawn among the traits recorded. All the required analysis was performed using Genstat 12th edition (Payne et al., 2007).

\section{Results and discussion}

One of the common problems associated with visual appraisal of grain mold is the difficulty to compare the results from workers using different assessment procedures and scales (ICRISAT, 1986). Though commonly used in resistance screening, visual appraisal alone does not always provide a satisfactory means of assaying fungal infection (ICRISAT, 1986). Ergosterol and flavan-4-ols are the two important biochemical traits which are directly associated with resistance to grain mold. Ergosterol is a steroid, which is specific to fungi. The quantity of ergosterol in a grain sample is an index of fungal mass (Sietz et al., 1977) and is another criterion for measuring grain mold damage apart from visual ratings. Flavan-4ols is the factor associated with resistance in cultivars with colored pericarp.

\subsection{Analysis of variance}

In the present study, estimation of ergosterol and flavan-4-ols was done in selected hybrids and their parents in 2004 and 2005. Individual ANOVA for the 2004 and 2005 rainy seasons depicted highly significant differences between hybrids and parents for FGS, TGS, percent germination, ergosterol and flavan-4-ols. The assumption of homoscedasticity was met in the data (data not shown) for all the traits except for ergosterol content. Hence the ergosterol data was transformed following Aitken's transformation to bring in homogeneity of error variances and thereby data was pooled. The genotypes were considered as fixed while the years and replications were considered as random effects. A combined analysis was performed to test the significance of hybrid $\times$ year interaction. The combined ANOVA suggested differential responses among the genotypes for all traits except for flavan-4-ols in acidified methanol extract and genotypes interacted significantly with the year for percent germination, flavan4-ols in methanol and acidified methanol extract (Table 1). The influence due to years was non-significant for all traits. From the combined ANOVA, it can be seen that the FGS, TGS and ergosterol showed highly significant genotype effects and non-significant effects due to year and its interaction effects with the genotype. Though significant genotype $\times$ environment interaction for ergosterol concentration was observed in earlier studies (Indira et al., 1991; Singh and Agarwal, 1993; Mansuetus et al., 1997; Tarekegn et al., 2006), the environment component of variance was more than genotype $\times$ environment variance component (Mpofu, 2009).

\subsection{Correlations}

Correlations between the different traits showed that FGS was significantly correlated with TGS as expected and that these two

Table 1

Combined analysis of variance (mean sum of squares) in 48 genotypes ( 25 hybrids, 22 parents and a susceptible check, Bulk Y) for the traits associated with grain mold resistance in sorghum in 2004 and 2005 rainy seasons.

\begin{tabular}{|c|c|c|c|c|c|c|c|}
\hline $\begin{array}{l}\text { Source of } \\
\text { variation }\end{array}$ & df & $\begin{array}{l}\text { Field } \\
\text { grade } \\
\text { score }\end{array}$ & $\begin{array}{l}\text { Threshed } \\
\text { grade } \\
\text { score }\end{array}$ & $\begin{array}{l}\text { Germination } \\
(\%)\end{array}$ & $\begin{array}{l}\text { Ergosterol } \\
\text { transformed } \\
\text { values }\end{array}$ & $\begin{array}{l}\text { Flavan- } \\
4 \text {-ols } \\
(\mathrm{Me})^{\mathrm{a}}\end{array}$ & $\begin{array}{l}\text { Flavan- } \\
\text { 4-ols } \\
(\mathrm{Me} / \\
\left.\mathrm{H}^{+}\right)^{\mathrm{b}}\end{array}$ \\
\hline Year & 1 & 3.11 & 6.02 & 25.52 & 59.7 & 0.23 & 0.16 \\
\hline Residual & 1 & 0.08 & 0.19 & 0.52 & 0.83 & 0.05 & 0.02 \\
\hline Genotype & 47 & $17.25^{* *}$ & $22.37 * *$ & $840.47^{* *}$ & $27.38^{* *}$ & 24.61 & $7.00^{* *}$ \\
\hline $\begin{array}{l}\text { Year } \times \\
\text { genotype }\end{array}$ & 47 & 1.42 & 1.67 & $67.18^{* *}$ & 1.63 & $0.11 * *$ & $0.32^{* *}$ \\
\hline Residual & 94 & 1.06 & 1.34 & 20.03 & 1 & 0.39 & 0.09 \\
\hline
\end{tabular}


Table 2

Phenotypic correlations between different variables in 25 sorghum hybrids. ${ }^{\text {a }}$

\begin{tabular}{lcccccc}
\hline & FGS & TGS & GER\% & ERGO & FLAV & FLAV + \\
\hline TGS & $0.92^{* *}$ & 1.00 & & & & \\
GER\% & $-0.94^{* *}$ & $-0.93^{* *}$ & 1.00 & & & \\
ERGO & $0.86^{* *}$ & $0.85^{* *}$ & $-0.92^{* *}$ & 1.00 & & \\
FLAV & -0.31 & -0.42 & 0.26 & -0.23 & 1.00 & \\
FLAV + & -0.26 & -0.39 & 0.23 & -0.22 & $0.94^{* *}$ & 1.00 \\
\hline
\end{tabular}

${ }^{*} P<0.05$ and ${ }^{* *} P<0.01$.

${ }^{\text {a }} \mathrm{FGS}=$ Field grade score, TGS $=$ Threshed grade score, GER $\%=$ Germination percentage, $\quad E R G O=$ Ergosterol $(u g / g), \quad F L A V=$ Seed flavan-4-ols $\left(A_{550} g^{-1}\right)$, FLAV $+=$ Seed flavan-4-ols in acidified methanol extract $\left(A_{550} \mathrm{~g}^{-1}\right)$.

traits were positively correlated with ergosterol content and negatively correlated with germination percentage (Table 2). Similar correlations were reported by earlier researchers (Seitz et al., 1983; Forbes, 1986; ICRISAT, 1986; Forbes et al., 1989; Jambunathan et al., 1991). Whereas, the correlations with flavan4-ols in methanol and acidified methanol extract were nonsignificant. This indicates that ergosterol content can be a reliable indicator for grain mold resistance. When the correlations of FGS with all other parameters was performed on individual groups of hybrids (Table 3), significant correlation coefficients of FGS were observed with TGS in susceptible hybrids, and percent germination and flavan-4-ols in colored susceptible hybrids. More importantly, the correlations were weak and non-significant in resistant hybrids, which further demonstrate that only highly significant differences can be visually scored in field (FGS). Bandyopadhyay and Mughogho (1988) also observed discrepancies with visual scoring method.

\subsection{Mean performance of hybrids in colored/white and resistant/ susceptible backgrounds}

\subsubsection{Mean performance for ergosterol content}

Grain mold resistant hybrids showed lower ergosterol concentrations than susceptible hybrids, while grain color did not seem to have much influence (Table 4). When the overall means were compared among the groups, ergosterol content was higher in susceptible hybrids $(19.49 \mu \mathrm{g} / \mathrm{g}$ ) compared to resistant hybrids $(9.96 \mu \mathrm{g} / \mathrm{g})$. Jambunathan et al. (1991) found 10 fold increase in ergosterol concentration in susceptible compared to resistant genotypes. Similarly, ergosterol content was higher in white $(17.2 \mu \mathrm{g} / \mathrm{g})$ hybrids as compared to red hybrids $(14.0 \mu \mathrm{g} / \mathrm{g})$. The results showed that the white hybrids were comparatively more susceptible than the red hybrids and these values correlated with that of FGS wherein resistant hybrids (FGS: 2.9) recorded 50\% less incidence than susceptible hybrids (FGS: 5.8 ) while the grain mold incidence of white hybrids (FGS: 4.1) was marginally more than

Table 3

Correlation matrix in resistant and susceptible, white and red colored sorghum hybrid groups for field grade score with other traits. ${ }^{\mathrm{a}}$

\begin{tabular}{|c|c|c|c|c|c|}
\hline Character & $\begin{array}{l}25 \\
\text { hybrids }\end{array}$ & $\begin{array}{l}\text { White } \\
\text { resistant }\end{array}$ & $\begin{array}{l}\text { Colored } \\
\text { resistant }\end{array}$ & $\begin{array}{l}\text { White } \\
\text { susceptible }\end{array}$ & $\begin{array}{l}\text { Colored } \\
\text { susceptible }\end{array}$ \\
\hline FGS & 1.00 & 1.00 & 1.00 & 1.00 & 1.00 \\
\hline TGS & $0.92 * *$ & 0.57 & 0.78 & $0.89^{*}$ & $0.93^{*}$ \\
\hline GER\% & $-0.94^{* *}$ & -0.58 & 0.03 & -0.86 & $-0.92 *$ \\
\hline ERGO & $0.86^{* *}$ & 0.14 & 0.41 & 0.83 & -0.11 \\
\hline FLAV & -0.31 & -0.06 & -0.46 & 0.72 & 0.86 \\
\hline FLAV+ & -0.26 & 0.60 & 0.03 & 0.63 & $0.89 *$ \\
\hline
\end{tabular}

${ }^{*} P<0.05$ and ${ }^{* *} P<0.01$.

a $\mathrm{FGS}=$ Field grade score, $\mathrm{TGS}=$ Threshed grade score, GER $\%=$ Germination percentage, $\quad \mathrm{ERGO}=$ Ergosterol $(\mathrm{ug} / \mathrm{g}), \quad \mathrm{FLAV}=$ Seed flavan-4-ols $\left(A_{550} \mathrm{~g}^{-1}\right)$, FLAV $+=$ Seed flavan-4-ols in acidified methanol extract $\left(A_{550} \mathrm{~g}^{-1}\right)$. red hybrids (FGS: 3.9). As both viable and non viable fungal biomass is measured by an ergosterol assay, the values are expected to correlate best with freshly harvested grain so that further invasion of the grain during storage is not measured (Sietz et al., 1977). The ergosterol content was also found to be highly correlated $(-0.92)$ with germination percentage. Forbes (1986) reported high correlation of ergosterol quantity with percentage germination than with seed mass or grain density. Though the ergosterol assay was found useful in selecting grain sorghum hybrids for resistance to grain weathering and discoloration (postphysiological maturity) primarily by Alternaria alternata (Seitz et al., 1983), these results also suggest the use of ergosterol for measuring the incidence of grain mold (pre-physiological grain deterioration).

\subsubsection{Mean performance for flavan-4-ols content}

Grain mold resistance has been found to correlate with concentration of flavan-4-ols in seeds (Butler, 1982; Jambunathan et al., 1991; Martinez et al., 1994; Audilakshmi et al., 1999). Similarly in the present study, the resistant hybrids had higher concentration of flavan-4-ols $\left(1.80 \mathrm{~A}_{550} \mathrm{~g}^{-1}\right)$ than the susceptible hybrids $\left(1.20 \mathrm{~A}_{550} \mathrm{~g}^{-1}\right.$ ) (Table 4). However, the differences were more pronounced in colored grain hybrids which recorded a concentration of $3.37 \mathrm{~A}_{550} \mathrm{~g}^{-1}$ compared to the white grain hybrids $\left(0.36 \mathrm{~A}_{550} \mathrm{~g}^{-1}\right)$ (Table 4). Similar trend was observed for flavan-4-ols in acidified methanol extract. Earlier studies also reported that the kernels of mold resistant red sorghum cultivars lacking pigmented testa contained more flavan-4-ols than did susceptible cultivars (Jambunathan et al., 1986, 1990; Mukuru, 1992). Flavan-4-ols is the factor associated with resistance in cultivars with colored pericarp. Tannins are involved in resistance in cultivars with pigmented testa. Neither flavan-4-ols nor tannins are associated with resistance in white-grained sorghum since these compounds are absent in white-grained cultivars (Hall et al. 2000).

\subsubsection{Heterosis for grain mold resistance in white/colored grain backgrounds}

About $90 \%$ of the hybrids in white grain background showed significant mid-parent heterosis for FGS, TGS and percent germination (Table 5). While in colored grain background, $60 \%$ of the hybrids had significant heterosis. For ergosterol content, about 90 to $100 \%$ of the hybrids were heterotic in white/colored grain backgrounds while for flavan-4-ols, $60 \%$ of the hybrids only in colored grain background had significant heterosis (Table 5). The considerable mid parent heterosis ( $>50 \%$ ) for ergosterol, FGS and TGS suggests the existence of dominance gene action for grain mold and the benefit of resistant hybrids for minimizing losses due to grain mold.

\subsection{Conclusions}

Sorghum grain mold is an important disease caused by a complex of fungi wherein ergosterol is a predominant sterol component in nearly all fungi. Researchers and breeders generally depend on visual examination of sorghum grains for selection of grain mold resistant genotypes. However, internal fungal colonization of the grain may not be accurately assessed from the visual scoring systems. Ergosterol and flavan-4-ols are two important biochemical tools that have been used to provide another measure of grain mold resistance. Since rainy season sorghum is mostly grown with hybrids, ergosterol content besides other traits were studied in hybrids. The data obtained from 25 hybrids for ergosterol and flavan-4-ols confirmed the earlier findings. Ergosterol content was $50 \%$ less in resistant hybrids though seed color 
Table 4

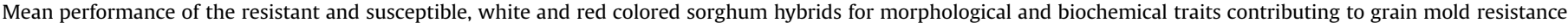
during 2004 and 2005 rainy seasons. ${ }^{a}$

\begin{tabular}{|c|c|c|c|c|c|c|c|c|}
\hline Hybrids & $\begin{array}{l}\text { Grain } \\
\text { color }\end{array}$ & FGS & TGS & $\begin{array}{l}\text { GER } \\
\%\end{array}$ & $\begin{array}{l}\text { Ergosterol } \\
\text { Transformed } \\
\text { values }\end{array}$ & $\begin{array}{l}\text { Ergosterol } \\
(\mathrm{ug} / \mathrm{g})\end{array}$ & $\begin{array}{l}\text { Flavan-4-ols } \\
(\mathrm{Me})\left(\mathrm{A}_{550} \mathrm{~g}^{-1}\right)^{\mathrm{b}}\end{array}$ & $\begin{array}{l}\text { Flavan-4-ols } \\
\left(\mathrm{Me} / \mathrm{H}^{+}\right)\left(\mathrm{A}_{550} \mathrm{~g}\right. \\
-1)^{\mathrm{c}}\end{array}$ \\
\hline \multicolumn{9}{|l|}{ White resistant hybrids } \\
\hline ICSA $400 \times$ IS41675 & White & 3.1 & 2.8 & 86 & 1.38 & 7.74 & 0.14 & 0.34 \\
\hline ICSA $400 \times$ ICSR 91011 & White & 3.0 & 3.5 & 91 & 1.67 & 9.52 & 0.70 & 0.28 \\
\hline ICSA $382 \times$ ICSR 91011 & White & 3.3 & 3.3 & 90 & 1.71 & 9.88 & 0.42 & 0.34 \\
\hline ICSA $101 \times$ ICSR 89058 & White & 3.1 & 4.0 & 91 & 1.46 & 8.38 & 0.28 & 0.22 \\
\hline ICSA $101 \times$ PVK 801 & White & 3.0 & 3.0 & 93 & 1.95 & 11.36 & 0.50 & 0.25 \\
\hline ICSA $52 \times$ IS 41675 & White & 3.7 & 4.5 & 88 & 2.21 & 12.63 & 0.59 & 0.45 \\
\hline ICSA $52 \times$ ICSV 96105 & White & 3.3 & 3.3 & 88 & 1.36 & 8.06 & 0.51 & 0.31 \\
\hline $\begin{array}{l}\text { ICSA } 384 \times \text { IS30469C-1508- } \\
\quad 2\end{array}$ & White & 3.8 & 4.3 & 85 & 1.61 & 9.40 & 0.20 & 0.31 \\
\hline ICSA $382 \times$ IS30469C-140-2 & White & 3.2 & 3.5 & 87 & 2.53 & 15.41 & 0.25 & 0.20 \\
\hline ICSA $400 \times$ ICSR 89058 & White & 3.1 & 4.3 & 88 & 1.89 & 10.74 & 0.31 & 0.17 \\
\hline Mean & & 3.3 & 3.6 & 88 & 1.78 & 10.31 & 0.39 & 0.29 \\
\hline \multicolumn{9}{|l|}{ Colored resistant hybrids } \\
\hline ICSA $400 \times$ GD 65028 & Red & 2.0 & 2.0 & 94 & 1.81 & 10.92 & 2.86 & 1.16 \\
\hline ICSA $384 \times$ GD 65028 & Red & 1.7 & 2.0 & 92 & 1.48 & 8.46 & 5.78 & 2.33 \\
\hline ICSA $382 \times$ GD 65028 & Red & 2.2 & 2.0 & 92 & 1.9 & 10.45 & 5.44 & 2.11 \\
\hline ICSA $101 \times$ GD 65028 & Red & 2.5 & 2.3 & 92 & 1.61 & 9.51 & 3.61 & 2.67 \\
\hline ICSA $371 \times$ GD 65055 & Red & 2.0 & 2.0 & 92 & 1.55 & 8.67 & 5.48 & 3.69 \\
\hline Mean & & 2.1 & 2.1 & 92 & 1.67 & 9.60 & 4.63 & 2.39 \\
\hline \multicolumn{9}{|l|}{ White susceptible hybrids } \\
\hline ICSA $384 \times$ IS $18758 C-618-3$ & White & 6.5 & 8.5 & 67 & 2.98 & 17.43 & 0.59 & 0.17 \\
\hline ICSA $52 \times$ IS 84 & White & 8.4 & 9.0 & 44 & 4.8 & 28.95 & 0.42 & 0.33 \\
\hline ICSA $52 \times$ ICSR 91011 & White & 4.8 & 7.3 & 76 & 2.86 & 17.71 & 0.23 & 0.28 \\
\hline ICSA $52 \times$ ICSR 92001 & White & 4.8 & 8.0 & 71 & 2.8 & 17.34 & 0.11 & 0.03 \\
\hline ICSA $384 \times$ ICSR 91019 & White & 5.1 & 8.0 & 61 & 3.54 & 21.45 & 0.11 & 0.00 \\
\hline Mean & & 5.9 & 8.2 & 64 & 3.40 & 20.58 & 0.29 & 0.16 \\
\hline \multicolumn{9}{|l|}{ Colored susceptible hybrids } \\
\hline ICSA $369 \times$ IS 84 & Red & 6.2 & 7.0 & 66 & 3.48 & 21.46 & 1.58 & 1.13 \\
\hline ICSA $369 \times$ IS $18758 C-618-3$ & Red & 4.5 & 5.5 & 79 & 3.11 & 18.13 & 1.18 & 0.85 \\
\hline ICSA $370 \times$ IS 84 & Red & 6.4 & 7.0 & 67 & 2.77 & 16.70 & 2.82 & 1.58 \\
\hline ICSA $371 \times$ IS 84 & Red & 7.0 & 7.0 & 68 & 2.97 & 17.76 & 3.49 & 1.98 \\
\hline ICSA $370 \times$ IS $18758 C-618-2$ & Red & 4.5 & 4.8 & 78 & 3.01 & 17.94 & 1.47 & 0.99 \\
\hline Mean & & 5.7 & 6.3 & 71 & 3.07 & 18.40 & 2.11 & 1.30 \\
\hline Grand mean & & 4.8 & 5.3 & 77 & 3.52 & & 1.75 & 0.94 \\
\hline lsd $(5 \%)$ & & 1.4 & 1.6 & 6 & 1.40 & & 0.88 & 0.41 \\
\hline
\end{tabular}

${ }^{\mathrm{a}} \mathrm{FGS}=$ Field grade score, TGS $=$ Threshed grade score, GER $\%=$ Germination percentage.

b Methanol extract.

c Acidified methanol extract.

did not have much influence on the quantity of ergosterol. Nonsignificant associations of flavan-4-ols with FGS, TGS and germination percentage were obtained from the current study. In contrast, the highly significant correlation of ergosterol content with germination percentage and FGS, TGS validates the use of this trait for the identification of grain mold resistant genotypes provided estimation is conducted shortly after harvest as fungal growth may increase during storage. There is a need to study the ergosterol content with delay in its estimation as one factor and the storage conditions as another factor before large scale evaluation for this trait. Also the significant heterosis obtained for this trait indicates the existence of dominance gene action and its further exploitation for benefiting the development of grain mold resistant hybrids.

Table 5

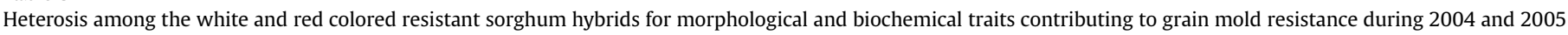
rainy seasons.

\begin{tabular}{|c|c|c|c|c|}
\hline \multirow[t]{2}{*}{ Trait } & \multicolumn{2}{|l|}{ White grain } & \multicolumn{2}{|l|}{ Colored grain } \\
\hline & Range of heterosis & $\%$ of hybrids with sig heterosis & Range of heterosis & $\%$ of hybridswith sig heterosis \\
\hline Field grade score & -19.3 to $-58.9 \%$ & 90 & -33.8 to $-62.2 \%$ & 60 \\
\hline Threshed grade score & -8.1 to $-60.7 \%$ & 90 & -36 to $63.6 \%$ & 60 \\
\hline Germination \% & 2.4 to $39.2 \%$ & 90 & 4.6 to $28.3 \%$ & 60 \\
\hline Ergosterol (ug/g) & -30.6 to -73.2 & 90 & -55.1 to $-68.7 \%$ & 100 \\
\hline Flavan-4-ols (Me) ${ }^{\mathrm{a}}$ & $\begin{array}{l}-67.4 \text { to } \\
202.7\end{array}$ & 0 & -49.1 to 1.1 & 60 \\
\hline Flavan-4-ols $\left(\mathrm{Me} / \mathrm{H}^{+}\right)^{\mathrm{b}}$ & 0.5 to 299.1 & 0 & -0.9 to 58.5 & 60 \\
\hline
\end{tabular}

a Methanol extract.

b Acidified methanol extract. 


\section{References}

Ambekar, S.S., Kamatar, M.Y., Ganesamurthy, K., Ghorade, R.B., Saxena, Usha, Chand, Pooran, Jadav, B.D., Das, I.K., Nageshwararao, T.G., Audilakshmi, S., Seetharama, N., 2011. Genetic enhancement of sorghum (Sorghum bicolor (L.) Moench) for grain mould resistance: II. Breeding for grain mould resistance. Crop Prot. 30, 759-764.

Andersen, P.P., Lorch, R.P., Rosegrant, M.W., 1999. World Food Prospects: Critical Issues for the Early Twenty-first Century. 2020 vision food policy report. International Food Policy Research Institute, Washington, DC, p. 30.

Audilakshmi, S., Stenhouse, J.W., Reddy, T.P., Prasad, M.V.R., 1999. Grain mold resistance and associated characters of sorghum genotypes. Euphytica 107, 91-103.

Bandyopadhyay, R., Mughogho, L.K., 1988. Evaluation of field screening techniques for resistance to sorghum grain moulds. Plant Dis. 72, 500-503.

Bartlett, M.S., 1937. Some examples of statistical methods of research in agriculture and applied biology. J. R. Stat. Soc. 4, 137-170.

Butler, L.G., 1982. Relative degree of polymerization of sorghum tannin during seed development and maturation. J. Agric. Food Chem. 30, 1090-1094.

Forbes, G.A., 1986. Characterization of grain mold resistance in sorghum (Sorghum bicolor L. Moench). Ph.D. dissertation, Texas A\&M University, College Station, Texas, USA. 75 pp.

Forbes, G.A., Frederiksen, R.A., Seitz, L.M., 1989. Assessment of sorghum grain mould: disease severity and crop loss. Seed Sci. Tech. 17, 297-307.

Ghorade, R.B., Shekar, V.B., Gite, B.D., Sakhare, B.A., 1997. Some general combiners for grain mould resistance in sorghum. J. Soils Crops 7, 8-11.

Hall, A.J., Bandyopadhyay, R., Chandrashekar, A., Shewry, P.R., 2000. Technical and institutional options for sorghum grain mold management and the potential for impact on the poor: overview and recommendations. In: Chandrashekar, A. Bandyopadhyay, R., Hall, A.J. (Eds.), Technical and Institutional Options for Sorghum Grain Mold Management: Proceedings of an International Consultation, 18-19 May 2000, ICRISAT, Patancheru, India Patancheru 502 324, Andhra Pradesh, India. International Crops Research Institute for the Semi-Arid Tropics, pp. 7-33.

Hodges, R.J., Hall, A.J., Jayaraj, K., Jaiswal, P., Potdar, N., Yoganand, B., Navi, S.S., 1999 Quality changes in farm-stored sorghum grain grown in the wet or dry season in South India - a technical and social study. NRI Report 2412. Chatham Avenue, Kent ME4 4TB, UK: Natural Resources Institute. 33 pp.

Ibrahim, O.E., Nyquist, W.E., Axtell, J.D., 1985. Quantitative inheritance and correlations of agronomic and grain quality traits of sorghum. Crop Sci. 25, 649-654.

ICRISAT (International Crops Research Institute for the Semi-Arid Tropics), 1986. Annual report 1985. Patancheru 502 324, Andhra Pradesh, India: ICRISAT. 367 pp.

Indira, S., Jitendra, M., Rana, B.S., 1991. Genotype x environment interaction for grain mould resistance and seed weight in sorghum. Ind. Phytopathol. 44, 523-525.

Jambunathan, R., Butler, L.G., Bandyopadhyay, R., Mughogho, L.K., 1986. Polyphenol concentration in grain, leaf and callus tissues of mould susceptible and mould resistant sorghum cultivars. J. Agric. Food Chem. 34, 425-429.

Jambunathan, R., Kherdekar, M.S., Bandyopadhyay, R., 1990. Flavan-4-ols concentration in grain mould-susceptible and mould-resistant sorghum at different stages of grain development. J. Agric. Food Chem. 38, 545-548.
Jambunathan, R., Kherdekar, M.S., Vaidya, P., 1991. Ergosterol concentration in moldsusceptible and mold-resistant sorghum at different stages of grain development and its relationship to flavan-4-ols. J. Agric. Food Chem. 39, 1866-1870.

Maiti, R.K., Raju, P.S., Bidinger, F.R., 1985. Studies on germinability and some aspects of preharvest physiology of sorghum grain. Seed Sci. Technol. 13, 27-35.

Mansuetus, A.S.B., Odvody, G.N., Frederiksen, R.A., Leslie, J., 1997. Biological species in the Gibberella fujikuroi species complex (Fusarium section Liseola) recovered from sorghum in Tanzania. Mycol. Res. 101, 815-820.

Martinez, M.J., Giorda, L.M., Balzrini, M., 1994. Relationship between resistance to grain mould concentration of flavan-4-ols of sorghum grain. Int. Sorg. Mill. Newslett. 35, 96-97.

Melake-Berhan, A., Butler, L.G., Ejeta, G., Menkir, A., 1996. Grain mold resistance and polyphenol accumulation in sorghum. J. Agric. Food Chem. 44, 2428-2434.

Mpofu, L.T., 2009. Analysis of genetic variability of grain mould resistance in sorghum. Ph.D. dissertation, Department of Plant Sciences, University of the Free State, Bloemfontein, South Africa. 194pp.

Mukuru, S.Z., 1992. Breeding for grain mould resistance. In: de Milliano, W.A.J. Frederiksen, R.A., Bengston, G.D. (Eds.), Sorghum and Millets Diseases: A Second World Review. International Crops Research Institute for the Semi-Arid Tropics, Patancheru, India, pp. 273-285.

Palakshappa, M.G., Hiremath, R.V., Sharmila, A.S., Padaganur, G.M., 2003. Development of sorghum genotypes resistant to grain molds. Karnataka J. Agric. Sci. $16,413-415$

Payne, R.W., Murray, D.A., Harding, S.A., Baird, D.B., Soutar, D.M., 2007. GenStat for Windows: Introd, 10th ed. VSN Intern, Hemel Hempstead.

Raju, N.S., Niranjana, S.R., Shekar Shetty, H., 2004. Ergosterol content in grain mold infected sorghum and its relationship with seed and nutritional qualities. J. Mycol. Plant Pathol. 34, 337-339.

Reddy, B.V.S., Bandyopadhyay, R., Ramaiah, B., Ortiz, R., 2000. Breeding grain mold resistant sorghum cultivars. In: Chandra Shekar, A., Bandyopadhyay, R., Hall, A.J. (Eds.), Technical and Institutional Options for Sorghum Grain Mold Management: Proceedings of an International Consultation, 18-19 May 2000. ICRISAT, Patancheru 502 324, Andhra Pradesh, India, pp. 195-224.

Schutt, C., Netzly, D. 1991. Effects of apiforol and apigeninidin on growth of selected fungi. J. Chem. Ecol. 17, 2261-2266.

Seitz, L.M., Mohr, H.E., Burroughs, R., Glueck, J.A., 1983. Preharvest fungal invasion of sorghum grain. Cereal Chem. 60, 127-130.

Sietz, L.M., Mohr, H.E., Burroughs, R., Sauer, D.B., 1977. Ergosterol as an indicator of fungal invasion in grains. Cereal Chem. 54, 1207-1217.

Singh, D.P., Agarwal, V.K., 1993. Grain mould of sorghum and its management. Agric. Rev. Karn. 14, 83-92.

Somani, R.B., Indira, I., 1999. Effect of grain molds on grain weight in sorghum. J. Mycol. Plant Pathol. 29, 22-24.

Tarekegn, G., McLaren, N.W., Swart, W.J., 2006. Effects of weather variables on grain mould of sorghum in South Africa. Plant Pathol. 55, 238-245.

Thakur, R.P., Rao, V.P., Navi, S.S., Garud, T.B., Agarkar, G.D., Bharati, B., 2003. Sorghum grain mold: variability in fungal complex. Int. Sorg. Mill. Newslett. 4, 104-108.

Thakur, R.P., Reddy, B.V.S., Mathur, K., 2007. Screening Techniques for Sorghum Diseases. Information Bulletin No. 76. International Crops Research Institute for the Semi-Arid Tropics, Patancheru, India, ISBN: 978-92-9066-504-505, 92 pp. 